\title{
23-G trocar-assisted cyclopexy: scleral sparing method as a new modality for large cyclodialysis repair
}

Ivan Cheng En Yoo, Yong Meng Hsien, Mushawiahti Mustapha, Jemaima Che Hamzah

Department of Ophthalmology, Universiti Kebangsaan Malaysia Medical Centre (UKMMC), Cheras, Wilayah Persekutuan Kuala Lumpur, Malaysia

\section{Abstract}

Cyclodialysis cleft results from separation of longitudinal ciliary muscle fibres from the scleral spur. The separation increases the uveoscleral outflow, leading to severe hypotony. Complexity in managing such condition relies on the extent of the injury and its collateral damage. We reported an alternative method of surgical repair for large cyclodialysis. The procedure was less invasive utilizing a scleral sparing technique. A 66-year-old gentleman presented with severe blunt trauma injury to the globe secondary to shuttlecock injury while playing badminton. He presented with a vision of hand motion. There was hyphaema (filling up half of the anterior chamber), complete posterior dislocation of the crystalline lens, and minimal vitreous haemorrhage. Posterior globe rupture was excluded with further imaging of the orbit. Despite significant amount of hyphaema, intraocular pressure (IOP) remained low several days post injury. Further investigations revealed the presence of almost $270^{\circ}$ of cyclodialysis. Surgical repair was indicated. In order to avoid an extensive cut on the sclera, the treating surgeon decided to explore a less invasive method utilizing a small gauge vitrectomy trocar. The main instruments used were the trocar, a straight prolene needle, and a bent $25-\mathrm{G}$ needle. The direction of trocar insertion plays a pivotal role in bringing the detached ciliary body back to its original position. The simplified technique did not require the creation of a scleral flap or direct

Correspondence: Assoc. Prof. Dr. Mushawiahti Mustapha, Department of Ophthalmology, Universiti Kebangsaan Malaysia Medical Centre (UKMMC), Jalan Yaacob Latif, Bandar Tun Razak, Cheras, 56000, Kuala Lumpur.

E-mail:drmusha@yahoo.com 
visualization of the ciliary body. The technique was fast and less invasive, with early improvement of IOP post intervention.

Keywords: hypotony, scleral sparing, traumatic cyclodialysis cleft

\section{Siklopeksi dibantu trokar 23-G: kaedah tanpa melalui sklera sebagai modaliti baru untuk merawat siklodialis yang besar}

\section{Abstrak}

Rekahan siklodialisis berlaku akibat pemisahan gentian otot ciliari membujur dari pangkal skleral. Pemisahan itu meningkatkan aliran keluar uveoscleral, yang membawa kepada hipotoni yang teruk. Kerumitan dalam menguruskan keadaan sedemikian bergantung pada tahap kecederaan dan kerosakan sekitarnya. Kami melaporkan kaedah alternatif pembedahan untuk siklodialisis yang besar. Prosedur itu kurang invasif menggunakan teknik tanpa melalui skleral. Seorang lelaki berusia 66 tahun yang mengalami kecederaan yang teruk pada mata semasa bermain badminton. Visual akuiti beliau ialah gerakan tangan. Terdapat hyphaema (mengisi separuh ruang anterior), dislokasi sepenuhnya kanta kristal kebahagian posterior, dan pendarahan vitreus yang minimum. Pengimejan orbit selanjutnya telah memastikan tiada pecah pada bahagian belakang mata. Walaupun pendarahan dalam ruang anterior adalah banyak, tekanan intraokular (IOP) kekal rendah beberapa hari selepas kecederaan. Siasatan lanjut sterusnya mendedahkan berlakunya hampir $270^{\circ}$ siklodialisis. Pembedahan pembedahanadalah dipelukan. Untuk mengelakkan pemotongan besar pada sklera, pakar bedah yang merawat memutuskan untuk meneroka kaedah yang kurang invasif dengan menggunakan trocar vitrectomi kecil. Alat utama yang digunakan ialah trokar, jarum prolene lurus, dan jarum 25-G yang bengkok. Arah penyisipan trokar memainkan peranan penting dalam membawa kembali jasad siliari yang terpisah ke kedudukan asalnya. Teknik mudah ini tidak memerlukan penciptaan flap skleral atau visualisasi langsung jasad ciliari. Teknik ini cepat dan kurang invasif, dengan penambahbaikan awal IOP selepas prosedur.

Kata kunci: hypotonik, scleral, rekahan siklodialisis akibat trauma 


\section{Introduction}

We report a case of extensive cyclodialysis due to blunt trauma that was treated successfully with surgical cyclopexy. In this case report, we share the optional technique of ciliary body suturing without the need to perform a scleral cut down, which has not been described previously.

\section{Case presentation}

A 66-year-old man suffered a shuttlecock injury over the right eye while playing badminton. He presented immediately to the eye clinic with visual acuity (VA) of counting fingers in the right eye (OD). He sustained traumatic mydriasis with hyphaema (Fig. 1). Reverse relative afferent pupillary defect (RAPD) was negative. There was a small conjunctival laceration with localized subconjunctival haemorrhage. Vitreous was present in the anterior chamber (AC) touching the inferior half of the corneal endothelium. His lens was completely dislocated posteriorly into the vitreous with concurrent vitreous haemorrhage. He had ocular hypotony OD with intraocular pressure (IOP) of $3 \mathrm{mmHg}$. Gonioscopic examination revealed a cyclodialysis cleft in the $1-5$ o'clock position. View was limited due to the presence of a blood clot in the AC angle. Despite the presence of hyphema, his IOP remained very low for a few days after the injury. Anterior segment optical coherence tomography (AS-OCT) and ultrasound biomicroscopy (UBM) revealed almost $270^{\circ}$ of cyclodialysis sparing only the 10-11 o'clock area (Fig. 2). Apart from the posteriorly dislocated crystalline lens and vitreous haemorrhage, gentle B scan did not reveal any retinal elevation or posterior globe rupture. Computer tomography scan of the orbit was also suggestive of an intact globe with no orbital injury.

Since there was no evidence of retinal detachment and the posterior condition was not in need of urgent intervention, the treating surgeon chose to normalise the IOP before posterior segment intervention by doing a two-staged surgery. The first surgery was aimed at stabilising IOP by repairing the cyclodialysis. Anterior vitrectomy with 23-G trocar-assisted cyclopexy was performed under general anaesthesia. Some amount of viscoelastic was left in situ to avoid early postoperative ocular hypotony. At day 1 post-operation, his IOP improved to $16 \mathrm{mmHg}$ and remained stable up until three weeks post-operation. Repeated AS-OCT showed reattachment of the ciliary body to the sclera (Figs. 3 and 4). Finally, the patient underwent a second procedure to remove the vitreous haemorrhage and dislocated lens, placing an encircling buckle for retinal dialysis as well as implanting a sutureless, scleral-fixated intraocular lens (IOL). His visual acuity improved to 6/18 postoperatively. 


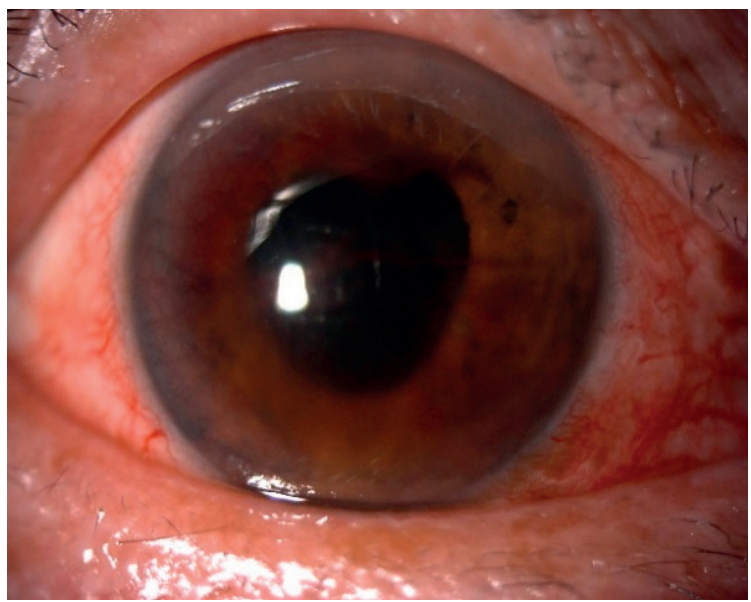

Fig. 1. Anterior segment photo OD shows vitreous and blood clots in the AC with absence of lens (dislocated posteriorly).

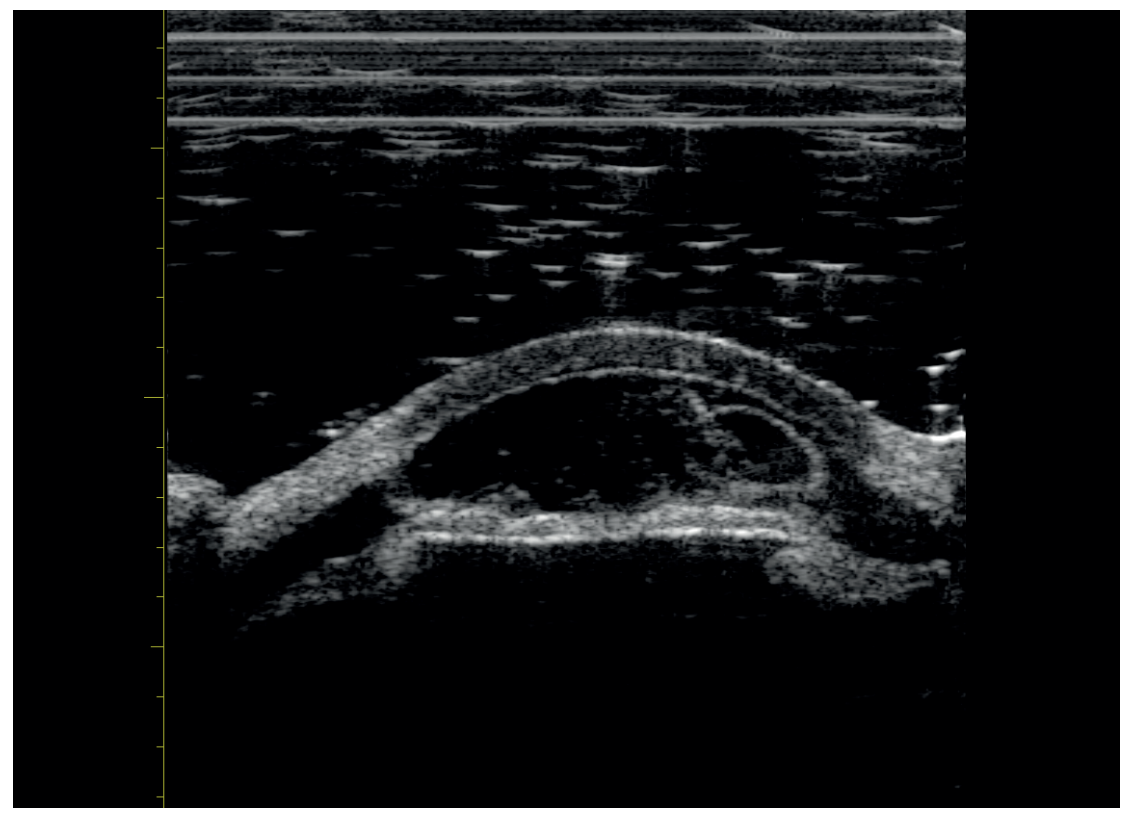

Fig. 2. UBM OD shows large cyclodialysis cleft. 


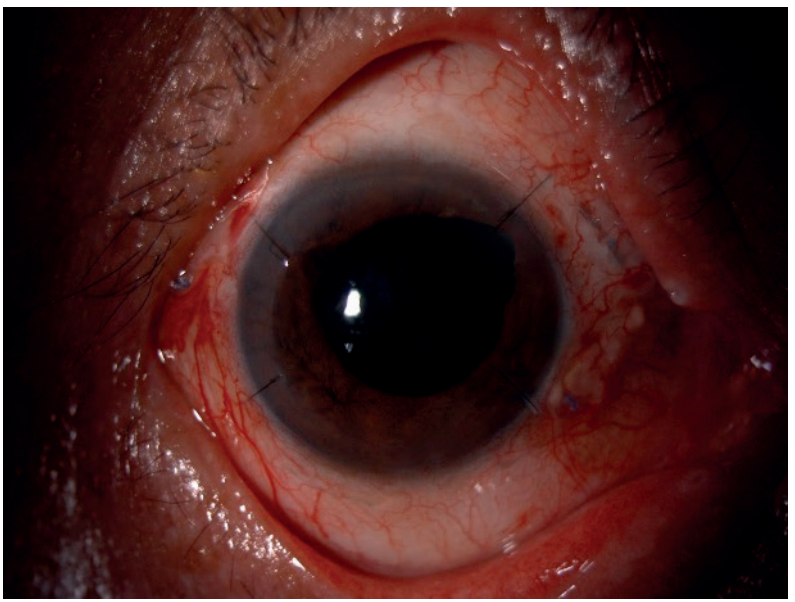

Fig. 3. Anterior segment photo OD after cyclodialysis repair with aphakia.

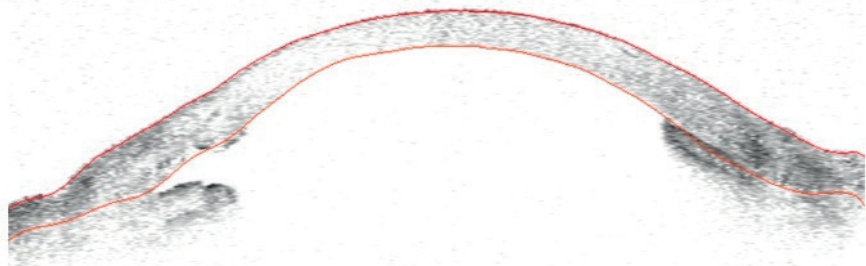

Fig. 4. AS-OCT OD shows reattachment of ciliary body to sclera after cyclopexy.

\section{Surgical technique of scleral-sparing cyclopexy}

The surgery was performed under general anaesthesia; the surgical technique is shown in Figures 5 and 6. Multiple points of entry into the AC were made at the $1,5,7$, and 11 o'clock positions (opposite to the area of the intended cyclodialysis repair). An AC maintainer was used throughout the surgery. Triamcinolone-assisted anterior vitrectomy was performed at the beginning of the surgery to remove the prolapsed vitreous.

Limited conjunctival peritomy was performed in three quadrants of the eye (corresponding to the cyclodialysis cleft area). A 23-G trocar was used for the repair. The direction of the trocar insertion was not performed in the traditional way of placing a port for posterior vitrectomy, in which the entry point is supposed to be $3-4 \mathrm{~mm}$ behind the limbus and traversing the sclera parallel to the limbus before complete entry into the vitreous. Instead, the trocar was inserted closer to the limbus; $1 \mathrm{~mm}$ from the limbus as the entry point then passed inside the sclera 3-4 $\mathrm{mm}$ posteriorly and later directly entered the eye at the pars plana area as the exit point. 


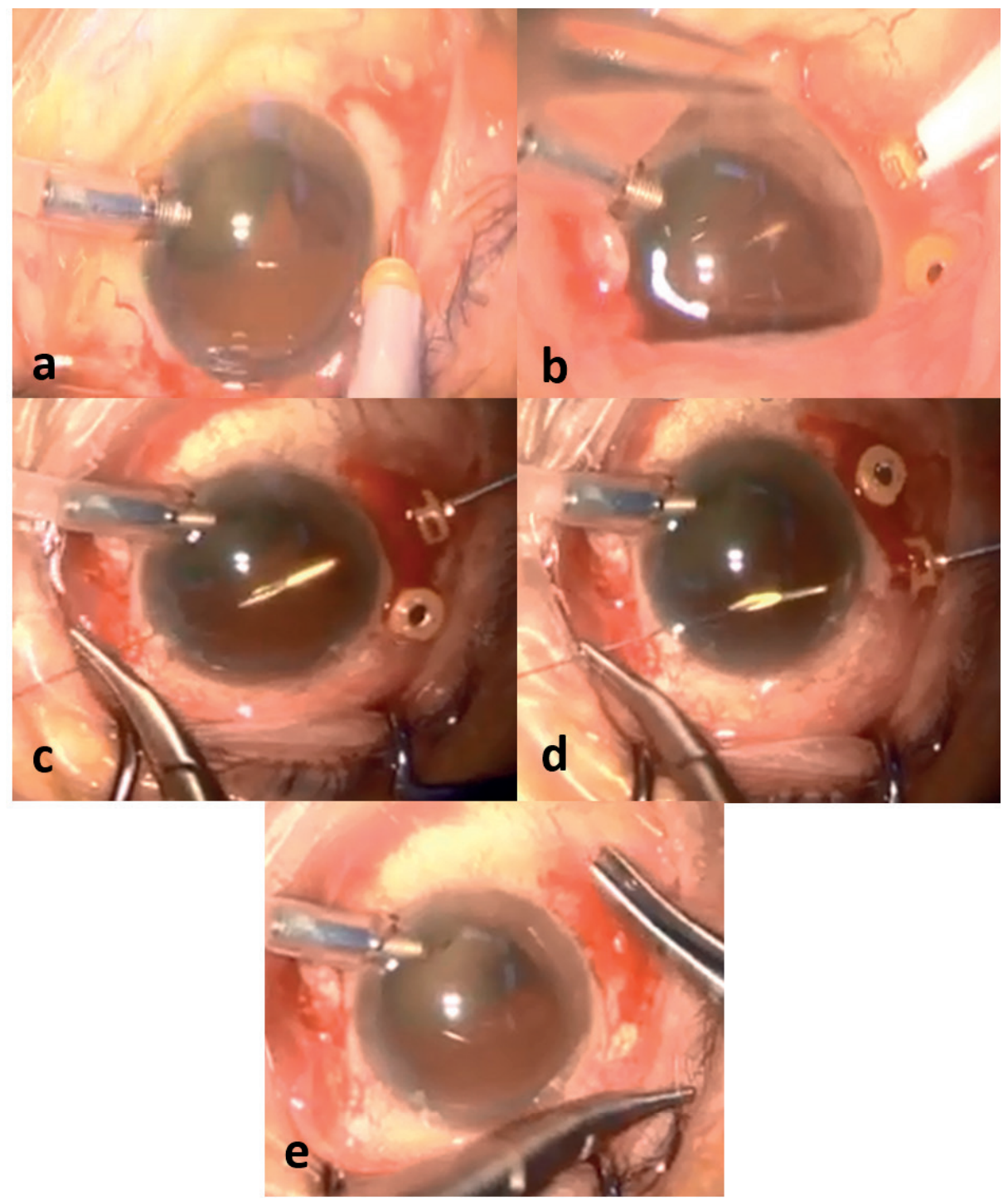

Fig. 5. Intraoperative photos of the of scleral-sparing cyclopexy surgical technique. A pair of trocars inserted $1 \mathrm{~mm}$ behind the limbus directed posteriorly $(a, b)$; double-ended prolene suture treadled through trocars $(c, d)$; and mattress suture to reattach the ciliary body $(e)$. 

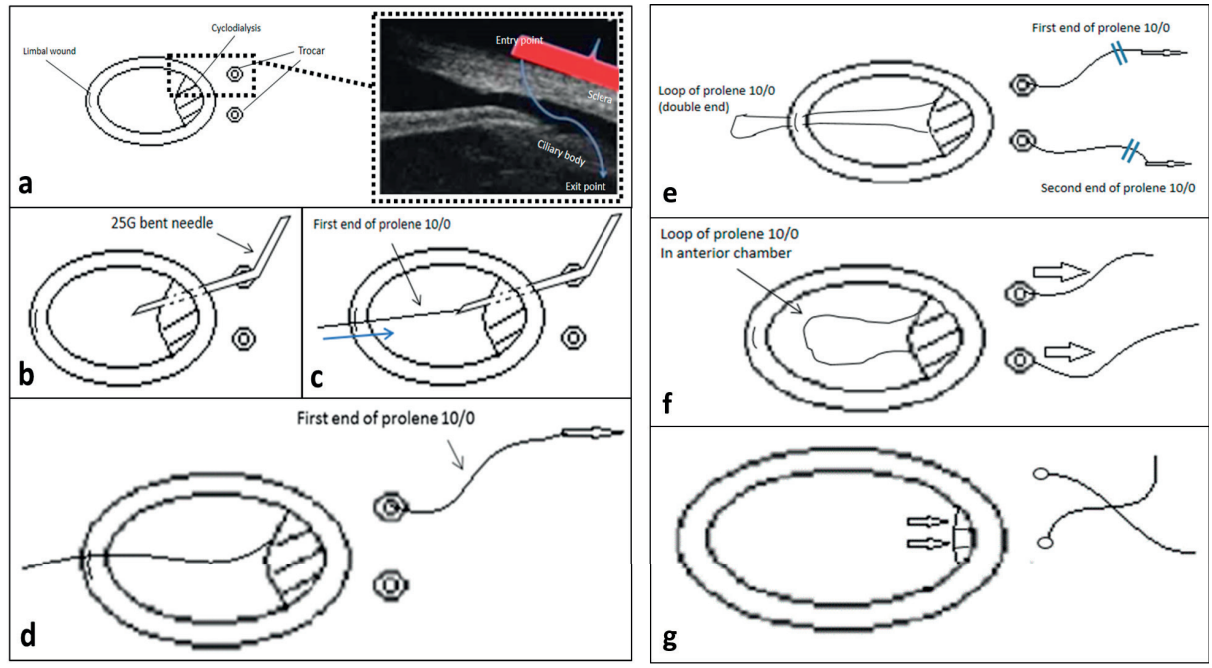

Fig. 6. Schematic diagrams of the scleral-sparing cyclopexy surgical technique. (a) Limited conjunctival peritomy was performed, followed by placement of a trocar at the area of intervention. A small limbal wound was created opposite to the area of interest. This limbal wound was used as the entry point for the double-ended prolene suture. The trocar was inserted 1 $\mathrm{mm}$ behind the limbus (entry point) and directed posteriorly, passing along the sclera for at least 3-4 $\mathrm{mm}$ before a direct entry point into the vitreous cavity was made (exit point of the trocar inside the vitreous cavity). (b) A $25-\mathrm{G}$ needle was bent at $45^{\circ}$. The bent needle was then inserted through the trocar passing through the cyclodialysis area. $(c)$ The double-ended 10/0 prolene suture (straight needle) was passed through the limbal wound and the tip of the prolene needle was partially inserted into the $25-G$ bent needle. $(d, e)$ The prolene suture was externalised by pulling out the bent 25-G needle, known as the handshake technique. (f) Once both ends of the prolene sutures were externalised, the preplaced trocars were removed, leaving only the prolene sutures in place. The ends of the sutures were tied together. Tightening of both sutures then retracted the detached ciliary body back to its original position. The knot was buried into the scleral pocket that was created during the initial insertion of the trocar. 
A second trocar was placed 1 o'clock hour away from the first trocar and inserted using the same direction as the first trocar. A straight, double-ended prolene 10/0 suture was used, with one end treadled through the first trocar from the opposite paracentesis wound, followed by another end of the suture treadled through the second trocar. The trocars were then removed and both suture ends were tied together. This manoeuvre automatically reapposed the detached ciliary body onto the sclera in posterior-anterior direction. Suture knots were buried into the scleral pocket that had been created by the longitudinal scleral entry of the initial trocar. The same steps were repeated in other quadrants. Using this technique, a wider area of cyclopexy was made without the need to create a partial scleral-thickness flap and completely avoiding the risk of bleeding while suturing the ciliary body into place. Cryotherapy was also performed in between the suture side.

Cryotherapy has been previously described for the repair of small cyclodialysis. Therefore, in our case, cryotherapy alone would not have been the best option. Hence, we combined intermittent suturing and cryotherapy to secure the large area of cilliary body detachment.

\section{Discussion}

Extensive cyclodialysis clefts are rare. They should be considered as one of the causes for persistent hypotony after trauma or surgery. Slit-lamp examination using a gonioscope is the most common method to detect the condition. ${ }^{1}$ However, with the presence of hyphaema, gonioscopy might not be the best option. AS-OCT and UBM, which are noninvasive, provide a high-resolution image of the cyclodialysis. Both imaging methods provide accurate and reproducible images of the anterior segment, ${ }^{2}$ not only helping to identify the condition, but also the extent of damage. The exact disinsertion point can be clearly identified using these two methods. AS-OCT produces high-resolution images with limited depth of penetration, whereas UBM allows deeper penetration of the anterior segment structures, even with presence of hyphema or corneal opacity. In our case, both methods were able to assist us in making the diagnosis as well as monitoring the resolution of the detached space postsurgery.

Cyclodialysis clefts cause persistent hypotony, corneal oedema, shallowing of the AC, refractive changes, cataract, choroidal effusion or detachment, retinal and choroidal folding, optic disc swelling, and maculopathy. ${ }^{3}$

The management of ciliary body detachment depends on the severity and associated intraocular abnormalities. Small clefts can be managed by medical therapy e.g. cycloplegic drugs. These medications cause relaxation of the ciliary muscle tone and dilatation of the ciliary body ring, thus opposing the detached muscle fibres to the sclera. ${ }^{4}$ If medical therapy by itself fails to close a cyclodialysis cleft, argon laser can be applied deep in the cleft, first to the sclera and then to 
the exposed ciliary muscle as well as to peripheral iris. Laser therapy functions by inducing local inflammation and seals the cleft by promoting adhesion between the choroid and sclera. ${ }^{5}$ Cryotherapy to the sclera is another noninvasive procedure to treat small cyclodialysis clefts with limited success rate. ${ }^{6}$

Clefts that respond poorly to nonsurgical treatment should be identified early and treated appropriately with feasible surgical strategies. ${ }^{7}$ Direct cycloplexy, which was previously described as being the gold standard for treatment of large clefts, involves creation of a limbal-based, partial-thickness scleral flap, followed by a stab incision over the area of cyclodialysis to incarcerate the iris, and subsequently, cryotherapy. ${ }^{8}$ Alternatively, some surgeons reported the technique of direct ciliary body suturing under the partial-thickness scleral flap to attach the cleft. ${ }^{9}$ Various reported techniques have their own limitations, such as severe intraoperative hypotony, damage to vascular structures with bleeding, disrupted filtering bleb function after trabeculectomy, and long recovery periods after surgery. ${ }^{10}$

Another reported surgical option is to combine vitrectomy and endophotocoagulation with silicone oil endotamponade (VEE). ${ }^{11}$ However, the intraocular surgery potentially leads to cataract, postoperative IOP spikes, and other tamponade-related complications. ${ }^{11}$ Cyclodialysis cleft repair can also be done by phacoemulsification combined with internal tamponade using modified capsular tension ring insertion (MCTR). It was postulated that the contact between the eyelets of the MCTR and the iridial posterior surface may lead to uveitis and IOP spikes. ${ }^{12}$

In our case, we describe a 23-G trocar-assisted cyclopexy technique. This method was chosen in view of multiple coexisting intraocular injuries. Minimising the complexity of surgery allows a shorter recovery time and reduces the likeliness of having long-term sequelae. Apart from sparing the sclera, the technique described reduces the chances of bleeding, infection, and intraoperative hypotony, and also results in less scarring over the conjunctiva. The technique we describe also allows early improvement of IOP with less complex surgery for large cyclodialysis repair.

\section{Conclusion}

Trocar-assisted ciliary body suturing could be one of the surgical approaches for large cyclodialysis repair. Potentially, this technique is less traumatizing to the eye and provides a broader area of treatment.

\section{References}

1. Tang J, Du E, Wang J. Novel surgical management of cyclodialysis cleft via anterior chamber perfusion: case report. Medicine (Baltimore). 2017;96:e7559. 
2. Mateo-Montoya A, Dreifuss S. Anterior segment optical coherence tomography as a diagnostic tool for cyclodialysis clefts. Arch Ophthalmol. 2009;127:109-116.

3. Aminlari A, Callahan CE. Medical, laser, and surgical management of inadvertent cyclodialysis cleft with hypotony. Arch Ophthalmol. 2004;122:399-404.

4. Dhiman R, Sobti A, Khandjuja S, et al. Management of cyclodialysis cleft. J Curr Glaucoma Pract. 2011;5:35-38.

5. Pinheiro-Costa J, Melo AB, Carneiro AM, et al. Cyclodialysis cleft treatment using a minimally invasive technique. Case Rep Ophthalmol. 2015;6:66-70.

6. Krohn J. Cryotherapy in the treatment of cyclodialysis cleft induced hypotony. Acta Ophthalmo Scand. 1997;75:96-98.

7. Chen J, Jing Q, Gao W, et al. Cyclodialysis cleft repair and cataract management by phacoemulsification combined with internal tamponade using modified capsular tension ring insertion. Graefes Arch Clin Exp Ophthalmol. 2018;256:2369-2376.

8. Tate GW Jr, Lynn JR. A new technique for the surgical repair of cyclodialysis induced hypotony. Ann Ophthalmol. 1978;10:1261-1268.

9. Chang RT. Cyclodialysis Cleft. Glaucoma Today. May/June 2012.

10. Murta F, Mitne S, Allemann N, et al. Direct cyclopexy surgery for post-traumatic cyclodialysis with persistent hypotony: ultrasound biomicroscopic evaluation. Arq Bras Oftalmol. 2014:77:50-53.

11. Xu WW, Huang YF, et al. Cyclopexy versus vitrectomy combined with intraocular tamponade for treatment of cyclodialysis. Int J Ophthalmol. 2013;6:187-192.

12. Yuen NS, Hui SP, Woo DC. New method of surgical repair for 360-degree cylodialysis. J Cataract Refract Surg. 2006;32:13-17. 